\title{
Summer spatial distribution of cetaceans in the Strait of Gibraltar in relation to the oceanographic context
}

\author{
Renaud de Stephanis ${ }^{1,2, *}$, Thomas Cornulier ${ }^{3,4}{ }^{2}$ Philippe Verborgh ${ }^{1,2}$, \\ Juanma Salazar Sierra ${ }^{1,2}$, Neus Pérez Gimeno ${ }^{2,5}$, Christophe Guinet ${ }^{3}$
}

\author{
${ }^{1}$ CIRCE, Conservation Information and Research on Cetaceans, C/Cabeza de Manzaneda 3, Algeciras-Pelayo, 11390 Cadiz, Spain \\ ${ }^{2}$ Sociedad Española de Cetáceos C/Nalon 16, La Berzosa, Madrid, Spain \\ ${ }^{3}$ Centre d'Études Biologiques de Chizé, CNRS UPR 1934, 79360 Villiers en Bois, France \\ ${ }^{4}$ School of Biological Sciences, Zoology Building, Tillydrone Avenue, University of Aberdeen, Aberdeen AB24 2TZ, UK \\ ${ }^{5}$ Laboratorio de Ingeniería Acústica de la Universidad de Cádiz (LAV), CASEM, Río de San Pedro S/N, Puerto Real, Cádiz, Spain
}

\begin{abstract}
The Strait of Gibraltar, the only passage between the Mediterranean Sea and the Atlantic Ocean, and characterised by a surface inflow of Atlantic waters and a deep outflow of Mediterranean waters, is inhabited by a large number of cetacean species. The present study focuses on the occurrence and the spatial distribution of cetacean species within the strait in relation to oceanographic features. Shipboard visual surveys were conducted during the summers of 2001 to 2004, covering $4926 \mathrm{~km}$. A total of 616 sightings of 7 cetacean species were made. The spatial distributions of 6 species (short-beaked common dolphins Delphinus delphis, striped dolphins Stenella coeruleoalba, bottlenose dolphins Tursiops truncatus, long-finned pilot whales Globicephala melas, sperm whales Physeter macrocephalus and killer whales Orcinus orca) were examined with respect to depth and slope. The analyses indicate that these species could be ordered into 3 groups. A first group, with a northward tendency, is composed of common and striped dolphins. Due to its at-sea location and feeding habits, this group is likely to feed on mesopelagic fishes or squids associated with the surface Atlantic waters. The second group, constituted by bottlenose dolphins, long-finned pilot whales and sperm whales, is mainly found over the deep waters of the central part of the strait. While the foraging ecology of bottlenose dolphins is still unclear, both sperm whales and pilot whales are most likely to feed on squids occurring in deep Mediterranean waters. The third group, formed by killer whales Orcinus orca, was associated with blue fin tuna Thunnus thynnus fisheries in the southwestern part of the strait.
\end{abstract}

KEY WORDS: Cetacean $\cdot$ Strait of Gibraltar $\cdot$ Spatial distribution $\cdot$ Feeding ecology $\cdot$ Fisheries interaction

\section{INTRODUCTION}

Cetacean distribution and abundance in the Strait of Gibraltar is poorly described and limited to a few sources. One of the latter relies on data from commercial whaling activities, which took place between 1921 and 1959 from shore-based whaling stations located in Getares (Spain) and Benzou (Morocco) and from factory ships (Aguilar 2006). But these data describe the situation in the Atlantic areas off the Strait of Gibraltar, and not the Strait of Gibraltar itself (Aguilar 2006). A survey conducted from ferries navigating between Spain and Morocco from March to May 1999 found that the main species encountered in the eastern part of the strait were the striped dolphin Stenella coeruleoalba, short-beaked common dolphin Delphinus delphis and, occasionally, bottlenose dolphin Tursiops truncatus, long-finned pilot whales Globicephala melas and sperm whales Physeter macrocephalus (Roussel 1999). Finally, studies from the Spanish drift- 
net fishery operating until 1994 in the strait also revealed the presence of common dolphin and striped dolphin (Silvani et al. 1999). In 2005, a study provided evidence of the presence of these species in the Alborán Sea (Cañadas et al. 2005). However, the relative density and the spatial distribution of the cetacean species encountered within the Strait of Gibraltar remain unknown.

The Strait of Gibraltar is the narrow and shallow connection between the Mediterranean Sea and the Atlantic Ocean (Fig. 1). The water circulation in the strait is characterised by: (1) a surface inflow of Atlantic waters, which is driven by the excess of evaporation over precipitation in this basin, and (2) a deep outflow of dense Mediterranean water (Lacombe \& Richez 1982). The strait is also characterised by mixing processes through pulsed upwelling induced by the tides and constrained by the bathymetry of the area (Echevarría et al. 2002).

The interface between the Atlantic surface waters and the deep Mediterranean waters generally takes place at a depth between 50 and $200 \mathrm{~m}$, depending on the geographic location and intensity of the tidal flows. The boundary between Atlantic waters and Mediterranean waters becomes deeper from the Spanish coast to the Moroccan coast (north to south) (Reul et al. 2002) and from the Atlantic to the Mediterranean (east to west), from approximately $100 \mathrm{~m}$ at $5^{\circ} 20^{\prime} \mathrm{W}$ to $300 \mathrm{~m}$ at $6^{\circ} \mathrm{W}$ in the central part of the strait (Kinder et al. 1988). This Atlantic-Mediterranean water interface is considered to be a biogeographic boundary (Sanjuán et al. 1994). Nevertheless, there is substantial transport of organisms across this ecotone. Most of the plankton biomass is transported into the Mediterranean Sea by Atlantic waters. Reul et al. (2002) estimated that $5570 \mathrm{t}$ $\mathrm{C} \mathrm{d}^{-1}$, dominated by autotrophic nanoplankton (42\%) and heterotrophic bacteria $(37 \%)$, is transported towards the Mediterranean Sea, while 1140 t C of heterotrophic organisms (89\%) is exported daily towards the Atlantic by the deep Mediterranean outflow.

The highest biomass concentrations were observed in the northern part of the strait, where enriched Atlantic shelf waters circulate (Van Geen \& Boyle 1988). However, due to higher current velocities, most of the biomass import took place in the central and southern parts of the strait, where we would expect to find high concentrations of cetaceans, as ecological studies of apex predators at sea indicate that their distribution and abundance can often be related to oceanographic features and marine productivity.

Bathymetry plays an important role on prey distribution (Gil de Sola 1993). This role can be direct, as on demersal prey, for which the distribution can often be related to topographic features such as depth and slope. For pelagic cetacean prey species, such as fishes or cephalopods, bathymetric features could act indi-

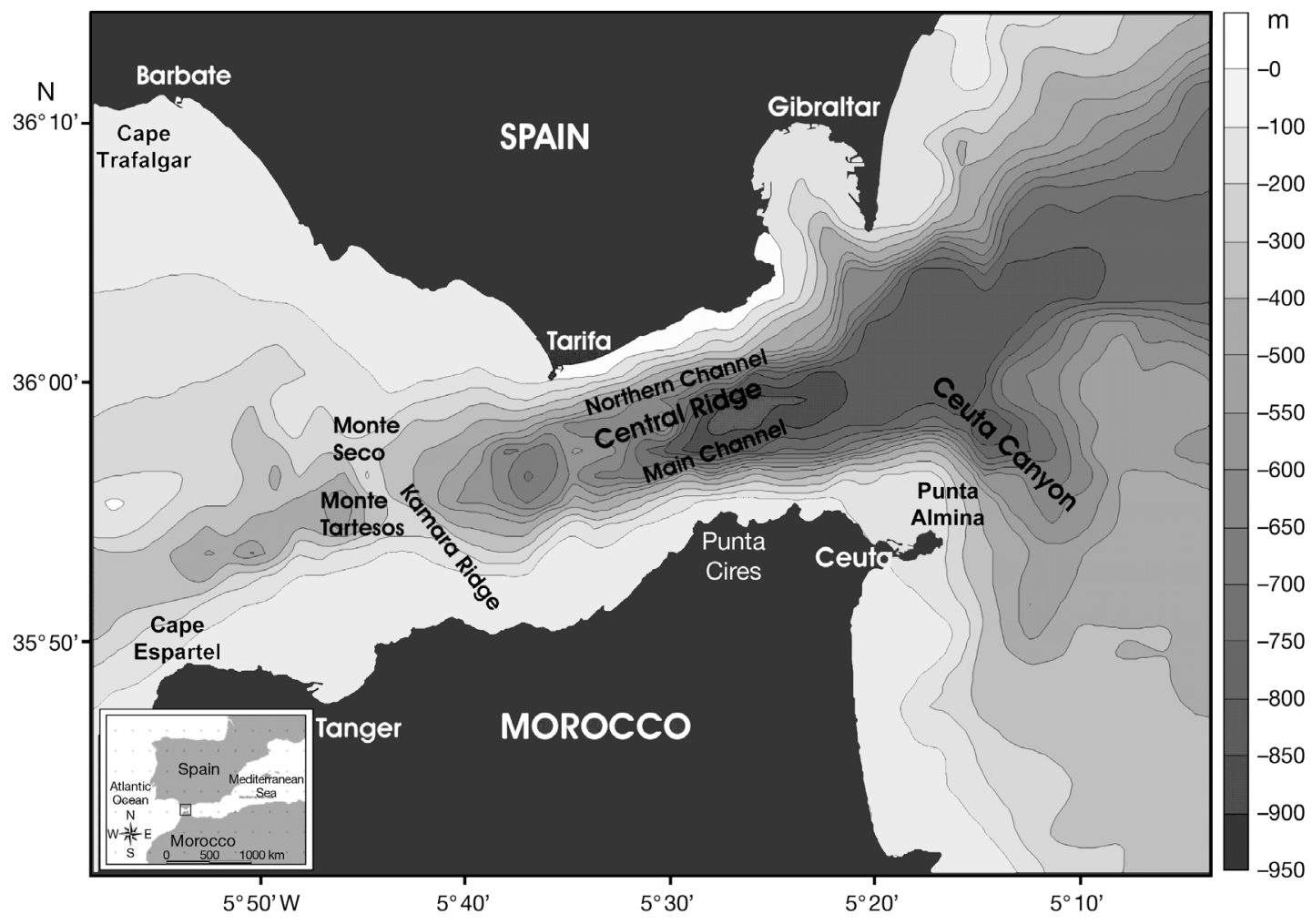

Fig. 1. Study area and bathymetry of the Strait of Gibraltar 
rectly through topographically induced vertical (upwelling) and horizontal (currents) circulation, both of which can stimulate the primary and secondary production, but could also act directly on the spatial distribution of prey species through transport and/or aggregating effects (Davis et al. 1998, Cañadas et al. 2005).

Modelling the relationships between cetacean distribution and environmental factors is a complicated task for several reasons. For instance, relationships between cetacean abundance and habitat features may be non-linear. To overcome this problem, many cetacean distribution studies have used generalised additive models (GAMs) that can fit non-parametric smoothing functions of the data (see e.g. Forney 2000, Redfern et al. 2006, Williams et al. 2006).

More importantly, cetacean surveys rarely follow systematic designs in space and time, due to specific logistical constraints, especially when conducted from opportunistic platforms (Williams et al. 2006). Therefore, sampling effort is typically heterogeneous and needs to be carefully accounted for (Redfern et al. 2006). Additionally, encounter rates with cetaceans are often very low, typically resulting in sparse data that are difficult to analyse, both in terms of abundance and probability of sighting. The problem is even more acute with species living in (potentially large) groups that tend to generate extremely skewed or overdispersed distributions of counts for which standard (e.g. binomial, Poisson, or log-normal) statistical models may not be suitable.

Additionally, animal distribution data are autocorrelated, especially for organisms like cetaceans, which live in schools. Accounting for spatial autocorrelation is vital when modelling the relations between animal distribution and the environment (Keitt et al. 2002). Although this restraint is recognised in cetacean literature, a recent review of this field suggests that very few, if any, studies have attempted to include spatial correlation in cetacean-habitat models (Redfern et al. 2006).

In the present paper we propose to deal with these issues within a single model-based approach. In accordance with, e.g., Williams et al. (2006), we use GAMs, while paying careful attention to controlling for error dispersion by using quasi-binomial methods (for presence/absence data). In addition, we show that spatial autocorrelation can be included explicitly in order to select more parsimonious cetacean-habitat models.

Our study focuses on the summer cetacean distributions in the Strait of Gibraltar with the aims: (1) to estimate the relative abundance of cetacean species, (2) to investigate how their distribution is related to the bathymetric features of the Strait of Gibraltar and (3) to examine the inter-specific spatial association in the Strait of Gibraltar in summer.

\section{MATERIALS AND METHODS}

Study area and surveys. The study area encompasses the Strait of Gibraltar and its contiguous waters, between 5 and $6^{\circ} \mathrm{W}$, including Spanish and Moroccan waters. The Strait of Gibraltar (Fig. 1) is nearly $60 \mathrm{~km}$ long. Its western border is located between Cape Trafalgar (Europe) and Cape Espartel (Africa), $44 \mathrm{~km}$ apart. The strait then narrows to the east to reach a minimum width of $14 \mathrm{~km}$ between Tarifa (Europe) and Punta Cires (Africa). Its eastern border is located between Gibraltar and Punta Almina (Africa), $23 \mathrm{~km}$ apart. The bathymetry of the strait is characterised by a west to east canyon, with shallower waters (200 to $300 \mathrm{~m}$ ) found on the Atlantic side and deeper waters (800 to $1000 \mathrm{~m}$ ) on the Mediterranean side (Fig. 1).

Survey transects were conducted from the CIRCE (Conservation, Information and Research on Cetaceans) research motorboat 'Elsa' (11 m length), sampling the study area throughout the months of July, August and September between 2001 and 2004. Transects were conducted without any pre-defined track for each of these surveys, but they were designed to cover the whole range of bathymetry in the strait every month by crossing the isobaths perpendicularly. While carrying out the surveys it was attempted to maximise the presence at sea, with restrictions due to the maritime traffic present in the area and the meteorological conditions. The sampling strategy was constant throughout the survey period. The area was surveyed at an average speed of 5.6 knots $\left(9.8 \mathrm{~km} \mathrm{~h}^{-1}\right)$. Searching effort stopped when a group of cetaceans was approached and started again when the sighting was ended, with a return to the course previously established.

The observers were placed on an observation platform, $4 \mathrm{~m}$ above the sea level. Two trained observers occupied the observation lookout post in $1 \mathrm{~h}$ shifts during daylight, with visibility over 3 nautical mile $(5.6 \mathrm{~km})$, assisted with $8 \times 50$ binoculars, covering $180^{\circ}$ ahead of the vessel. Sighting effort was measured as the number of kilometres travelled with adequate sighting conditions (i.e. with a sea state Douglas of $<4$ and 2 observers at the lookout post. The Douglas sea state estimates the sea's roughness for navigation.)

The geographic position of the ship was recorded every minute on the ship's computer from a GPS (global positioning system) navigation system logger using the IFAW (International Fund for Animal Welfare) Data Logging Software Logger 2000, Version 2.20 (available at: www.ifaw.org/ifaw/general/default.aspx ?oid=25739). Data concerning the location and time of a sighting and the species, number of individuals and behaviour were recorded along with ancillary environmental data (sea state, wind speed, visibility). These 
environmental data were also taken every $20 \mathrm{~min}$, and at every course change of the boat.

According to the Sociedad Española de Cetaceos (SEC 1999), a sighting was defined as a group of animals of the same species seen at the same time, showing similar behaviour and for which the maximum distance between 2 individuals was $<1000 \mathrm{~m}$. When a group of animals was first seen, the location of the ship, and the distance and bearing of the cetaceans were recorded, to be able to localise the animals when approaching them. The location of the animals was also recorded when they had been approached by the vessel (i.e. $<100 \mathrm{~m}$ away). Eighty-eight groups of cetaceans were sighted, but not all were approached (see Table 1). The observation effort did not take into account the kilometres sailed while tracking the animals.

The study area was divided into quadrats, with a cell resolution of 2 min latitude ( $3704 \mathrm{~m}$ ) by 2 min longitude (3006 m) (Fig. 2). This scale was used to be able to compare these results with results gathered in future research programs carried out by members of the Spanish Cetacean Society. The distance in kilometres searched in each quadrat was calculated using a Geographic Information System: Arc View 3.2 from ESRI and its extension Animal Movement (Hooge \& Eichenlaub 2000). Only cells with sighting effort of at least $3 \mathrm{~km}$ were used for the analysis (Fig. 2).

Presence of cetaceans and relative abundance. Two parameters were defined to quantify cetacean relative abundance. (1) The encounter rate (ER) is the number of sightings of a given species per $100 \mathrm{~km}$ and is defined as: $\mathrm{ER}=($ Sigh/Eff $) \times 100$, where Sigh is the number of sightings made of a species versus effort in the research area, including all sightings whether the animals were approached or not, and Eff is the distance $(\mathrm{km})$ covered versus effort. (2) The abundance rate $(\mathrm{AR})$ (ind. $\mathrm{km}^{-1}$ ) was defined as: $\mathrm{AI}=(\mathrm{Ind} / \mathrm{Eff}) \times$
100 , where Ind is the number of individuals of a given species observed versus effort in the research area, including only sightings when the animals were approached, and Eff is the distance $(\mathrm{km})$ covered versus effort.

Spatial distribution and bathymetry. The encounter rate for each species was calculated for each quadrat using the number of sightings per species per $100 \mathrm{~km}$ searched, pooled over the $4 \mathrm{yr}$ of the study. Only sightings for which approach was established (i.e. the animals' location was within a $100 \mathrm{~m}$ radius of the boat's GPS position) were used for these analyses because some species, like sperm whales, are visible several kilometres away from the survey track and conversely could not be located precisely.

Two bathymetric features were assessed: the depth and the slope. Mean depth and slope were calculated for each quadrat. Depth was obtained from the ETOPO2v2 global elevation data set $\left(2^{\prime} \times 2^{\prime}\right)$; mean depth (range from 0 to $850 \mathrm{~m}$ ) was calculated for each quadrat. The bathymetric gradient was defined as the maximum slope around each pixel from the local slopes in $x$ and $y$. Only neighbours above, below, left and right of the pixel are accounted for in this 'rook's case procedure', and the largest value was kept. The algorithm IDRISI Module Surface Analysis computes the percent slope for each pixel using the 'tangent' trigonometric function. Slope values were expressed in metres per kilometre and ranged from a minimum of 0 to a maximum of $240 \mathrm{~m} \mathrm{~km}^{-1}$. Analyses of distribution of cetaceans according to depth and slope were made based on a continuous depth and slope data set (i.e. the mean values of quadrats), but depth and slope were ranked into subjective depth and slope categories to provide a pertinent ecological context for the interpretation of the results (Figs. $3 \& 4$ ). The depth was categorised according to the diving capabilities of the cetaceans observed in this study: 0 to $200 \mathrm{~m}$ (reachable

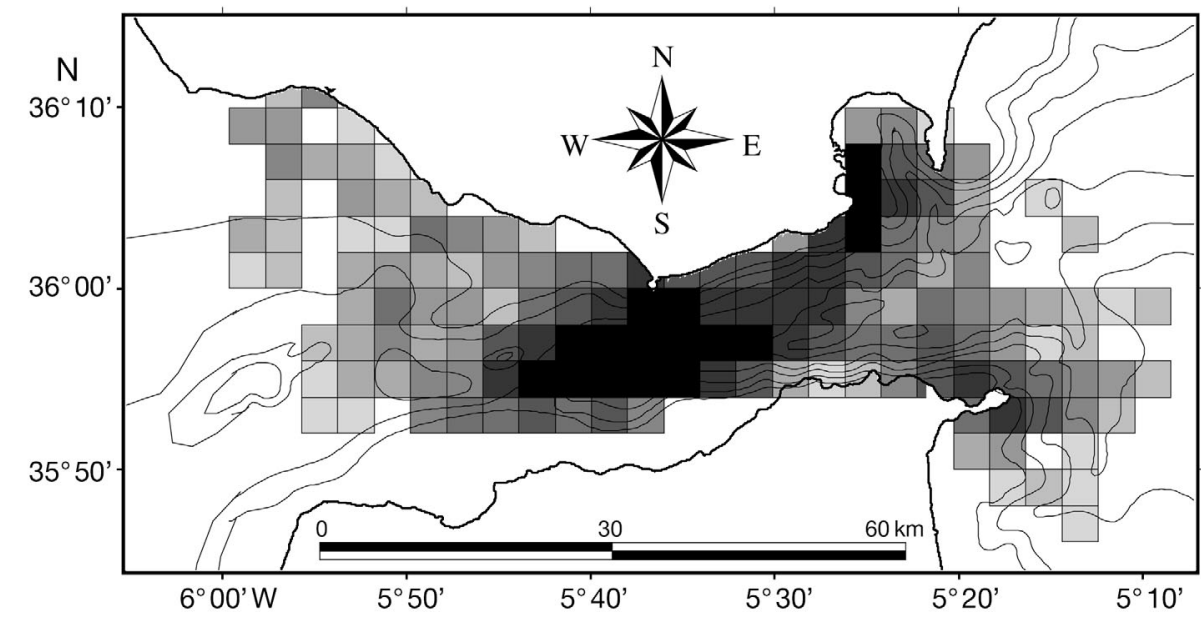

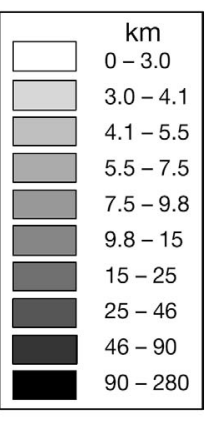

Fig. 2. Distribution of the observation effort in kilometres spent by quadrat over the study area 


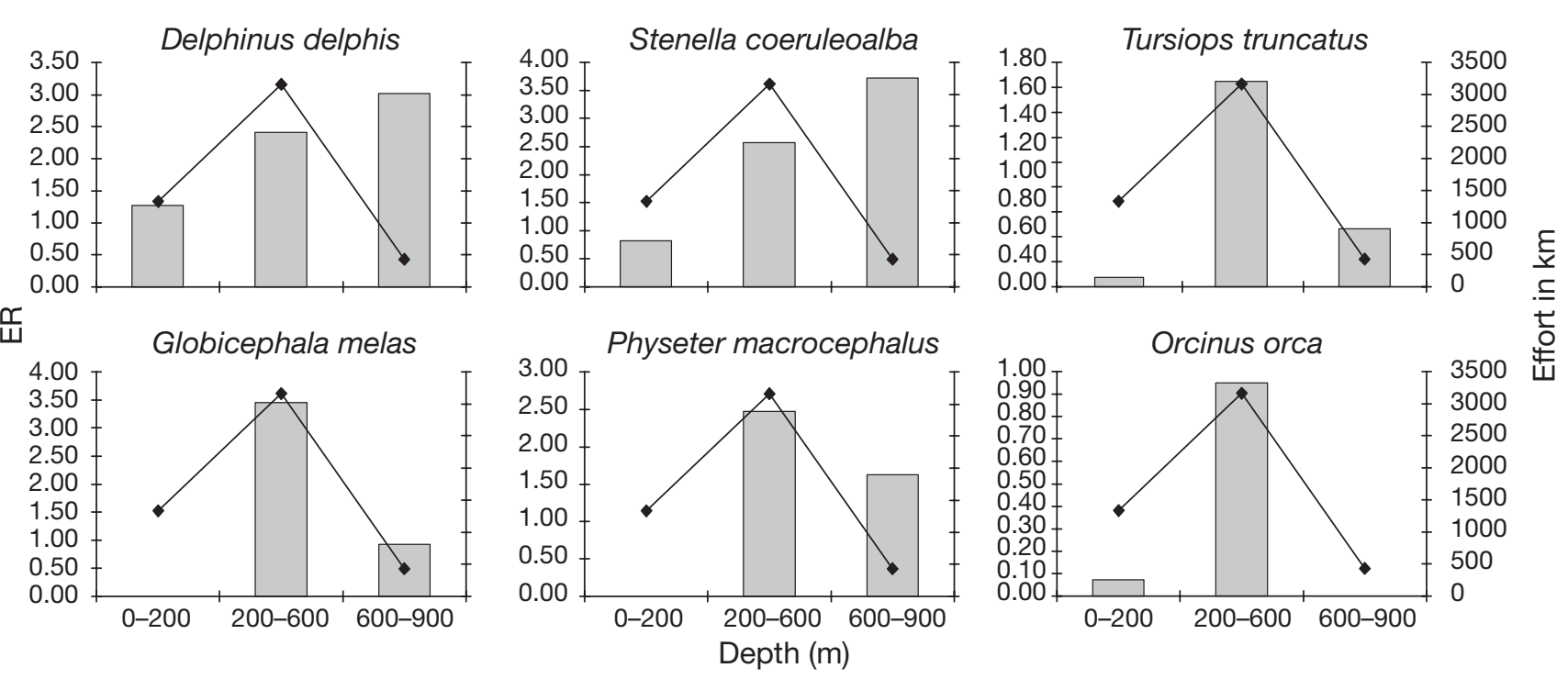

Fig. 3. Distribution of encounter rate (bars) and effort in kilometres $(\bullet)$ in relation to depth

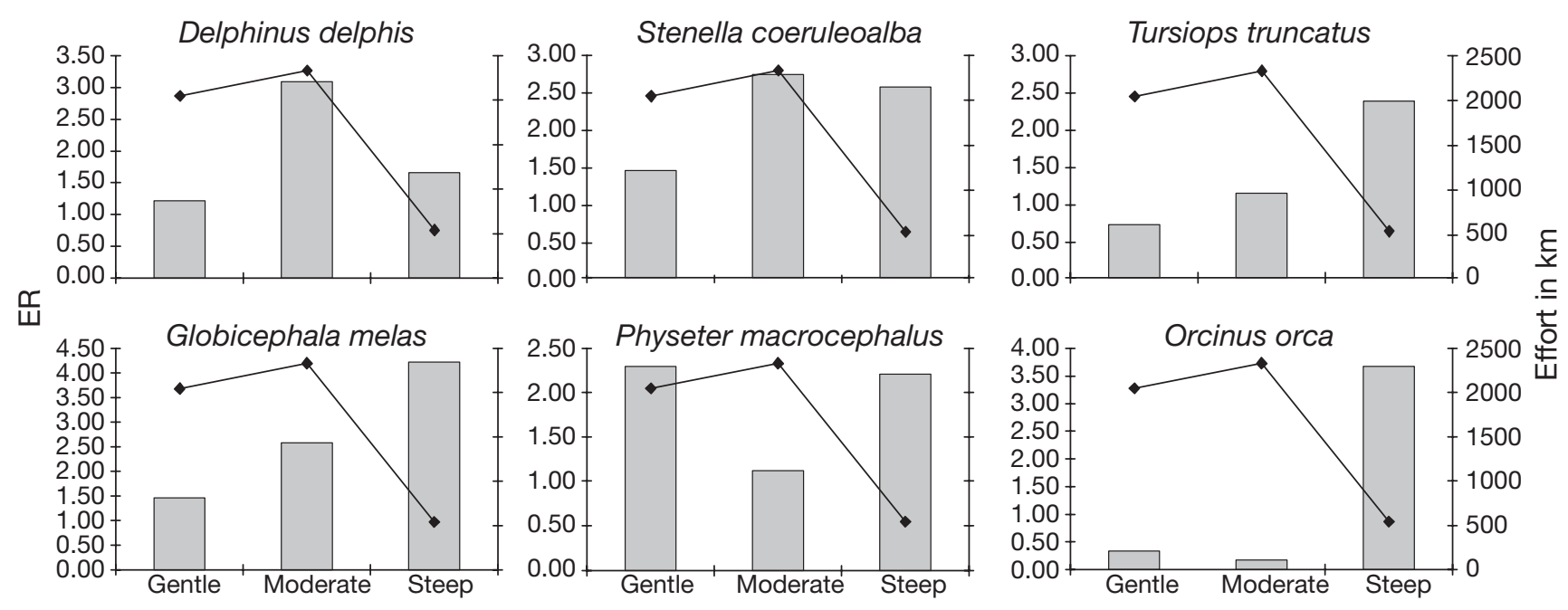

Fig. 4. Distribution of encounter rate (bars) and effort $(\bullet)$ in relation to slope

by all species), 200 to $600 \mathrm{~m}$ (typical depth of longfinned pilot whales) and $>600 \mathrm{~m}$ (reachable mostly by sperm whales). The slope was categorised following the categories of Piatt et al. (2006) as gentle (0 to $80 \mathrm{~m}$ $\mathrm{km}^{-1}$ ), moderate (80 to $160 \mathrm{~m} \mathrm{~km}^{-1}$ ) and steep (160 to $240 \mathrm{~m} \mathrm{~km}^{-1}$ ).

The relationships between species probability of presence, encounter rates and environmental variables were investigated using generalized additive mixed effects models (GAMMs), using the 'gamm' function of the 'mgcv' library (Wood 2006) in R 2.4.1 (R Development Core Team 2006). Smooth terms were used in order to allow for non-linear responses to the covariates, and spatial autocorrelation was accounted for by including a spherical or exponential correlation struc- ture in the model. The 2 covariates used were the continuous measures of depth and slope, which were significantly correlated in this data set $(\mathrm{n}=141, \mathrm{r}=0.23$, $\mathrm{p}=0.005)$. However, this correlation was sufficiently low to justify including both covariates in the models. The degree of smoothing for the non-linear terms was selected as part of the model fitting procedure using the default generalised cross-validation method (GCV) implemented in the 'gamm' function (Wood 2006). As for correlation structure, we used both the exponential model [the correlation between 2 points the distance $r$ apart is modelled as: $(1-n) \times \exp (-r / d)$, where $d$ is the range and $n$ is the nugget effect, i.e. the correlation at distance 0 and $r$ is the Euclidian distance], and the spherical model \{correlation is modelled as: $(1-n) \times[1$ 
$\left.-1.5(r / d)+0.5(r / d)^{3}\right]$, and takes the value 0 if $\left.r \times d\right\}$, as implemented by the 'corExp' and 'corSpher' functions of the 'nlme' library for mixed-effect models in R (Pinheiro \& Bates 2000). The range is the distance until 2 observations are correlated. Beyond this distance, they are considered independent. The nugget is the correlation at a distance near zero. Variograms were estimated using defaults of the function, i.e. using 50 distance lags covering the whole range of distances in the study area. The spherical and exponential models are among the most versatile and commonly used correlogram models and proved satisfactory in all the situations we encountered; therefore, no other model was tried. The choice between the 2 types of correlation structures was based on minimising the deviance of the models and by visually checking the variogram. When the exponential and spherical models gave indistinguishable results, the spherical was chosen because of its range parameter (i.e. the distance beyond which 2 observations are independent) has a more intuitive interpretation. We did not attempt to include any anisotropy in the spatial correlation structure because: (1) anisotropic correlograms are not currently implemented in the 'nlme' library (Pinheiro \& Bates 2000) used for the spatial component of the GAMMs and (2) it is reasonable to assume that the only likely source of anisotropy in this data set would be related to the east-west orientation of the Strait of Gibraltar's topography, which is already accounted for by our covariates (depth and slope).

For all species, a large number of grid cells had ER equal to zero. Quasi-binomial GAMM was used after converting into presence/absence data. Quasi-binomial models are logistic regressions (binomial error) allowing for under- or over-dispersion. Because ER was more variable in less intensively surveyed cells, observation effort per cell (in $\mathrm{km}$ ) was included as a covariate, assuming that the probability of sighting a species in a given cell is proportional to the observation effort. Model selection was based on a forward selection approach. Covariates were retained in the model when the associated coefficient was significantly different from zero.

For the species with the largest number of sightings (common dolphin and striped dolphin), we repeated the models on a yearly basis in order to check if the relation to environmental covariates differed from one year to another. For the other species, the numbers of quadrats with recorded presence were too few per year to expect reliable results: bottlenose dolphin (maximum number of quadrats in which presence was recorded in one given year $=8$ ), pilot whale $(12)$, killer whale (4) and sperm whale (11).

Overlap in distribution. The strength of the spatial relationships between pairs of species was represented using 2 indices of the frequency of co-occurrence: the half-weight association index and the simple ratio association index (Ginsberg \& Young 1992). However, as the inferences drawn were the same for the 2 indices, only values of the half-weight association index will be presented. Species present in the same quadrat were considered associated for this quadrat. To illustrate the association patterns of the species, average-linkage cluster analyses (Manly 1994) were constructed (see Fig. 12). We used permutation tests (Bejder et al. 1998) to test whether the association patterns of the observed species were different from what might be expected at random. An observed standard deviation of the pairwise association indices that is significantly larger than those from permuted data sets is taken as evidence that species share or avoid the quadrates with other species (Bejder et al. 1998). All quadrats were included; 20000 permutations were generated for each test; and to ensure that $\mathrm{p}$-values were stable, 6 runs of the permutation test were generated using the simple ratio and half-weight association indices in 3 runs each.

Boat distribution. The distribution of blue fin tuna Thunnus thynnus fishing boats was assessed to test if it was related to the distribution of cetacean species. Every $20 \mathrm{~min}$, a sampling station was established during the surveys, and tuna boats fishing within 1 mile were counted. If there was a doubt regarding the distance, a Radar JRC 1000 was used to estimate the distance of the boats. The type of fishing boat was confirmed using binoculars. The mean number of tuna boats was then calculated in each quadrat where at least 5 sampling stations had been conducted (results see Fig. 11).

\section{RESULTS}

\section{Search effort in the research area}

A total of $6332 \mathrm{~km}$ of transect were covered in the research area during the months of July, August and September 2001 to 2004. Of those, $4926 \mathrm{~km}$ were surveyed during the effort transects. They encompassed 150 quadrats, which represent $1670 \mathrm{~km}^{2}$ (Fig. 2).

\section{Cetacean presence and relative abundance}

A total of 606 sightings of 7 species were recorded (in 24 of which the species could not be identified) within the research area on effort, and were thus used for the calculation of the general ER. In 518 sightings (in 4 of which the species could not be identified), the cetaceans were approached, and these sightings were 
used to calculate the ER and AR in each quadrat (Table 1). Mean numbers of individuals in the groups for each species are given in Table 1. Fig. 2 shows the distribution of the encounter rates with respect to the depth. In terms of sightings, the most commonly observed species were the sperm whale Physeter macrocephalus and the long-finned pilot whales Globicephala melas. The less commonly observed species were the fin whale Balaenoptera physalus, with only 3 sightings, and the killer whale Orcinus orca (Table 1). When the mean number of individuals present within a group is taken into account, the most abundant species were the striped dolphin Stenella coeruleoalba and the common dolphin Delphinus delphis, while the less commonly seen species were the fin whale and the sperm whale (Table 1).

\section{Distribution in relation to bathymetric features}

Due to their low ER, fin whales were excluded from these analyses. The distribution of the ER, with respect to the effort in each interval of depth and slope for the 6 most commonly seen species of cetaceans is shown in Figs. 3 \& 4 . The spatial distribution of their ER is presented in Figs. 5 to 10. The analyses of the spatial distribution of cetacean species within the strait are summarised in Table 2.

Common dolphins Delphinus delphis were observed in $31.3 \%$ of the quadrats sampled and were more likely to be encountered in the northern part of the Strait of Gibraltar (Fig. 5). There was a clear positive linear effect of observation effort and slope on the dolphin's probability of presence in a cell, and no significant effect of the depth (Table 2). We repeated the quasi-binomial models on a yearly basis, assuming a linear effect of each covariate in order to obtain parametric coefficients. Depth did not appear significant in any year, and the slope had a significant positive effect in $2001(0.011 \pm 0.004, \mathrm{p}=0.01$, $\left.\mathrm{N}_{\text {approached }}=32, \mathrm{~N}_{\text {surveyed }}=119\right), 2002(0.030 \pm 0.011$, $\left.\mathrm{p}=0.005, \mathrm{~N}_{\text {approached }}=19, \mathrm{~N}_{\text {surveyed }}=80\right)$, but not in 2003 $\left(0.012 \pm 0.012, \mathrm{p}=0.32, \mathrm{~N}_{\text {approached }}=6, \mathrm{~N}_{\text {surveyed }}=81\right)$ or $2004\left(-0.001 \pm 0.014, \mathrm{p}=0.93, \mathrm{~N}_{\text {approached }}=4, \mathrm{~N}_{\text {surveyed }}=\right.$ 47 , which is most likely a result of insufficient statistical power.

Striped dolphins Stenella coeruleoalba were observed in $32.7 \%$ of the quadrats sampled (Fig. 6). The species presence was positively and linearly related to the observation effort, the depth and the slope of the sea bottom (suggesting that striped dolphins occur in the deepest and steepest parts of the strait) (Table 2). The quasi-binomial models were fitted again on a yearly basis, assuming, in turn, a linear effect of depth and slope. Depth had a significant positive effect on the probability of presence in $2001(0.004 \pm 0.001, \mathrm{p}=$ $\left.0.0003, \mathrm{~N}_{\text {approached }}=32, \mathrm{~N}_{\text {surveyed }}=119\right)$ and $2004(0.006$ $\left.\pm 0.003, \mathrm{p}=0.039, \mathrm{~N}_{\text {approached }}=9, \mathrm{~N}_{\text {surveyed }}=47\right)$, but not in $2002\left(-0.001 \pm 0.002, \mathrm{p}=0.60, \mathrm{~N}_{\text {approached }}=24\right.$, $\left.\mathrm{N}_{\text {surveyed }}=80\right)$ or $2003(-0.0003 \pm 0.002, \mathrm{p}=0.88$, $\left.\mathrm{N}_{\text {approached }}=8, \mathrm{~N}_{\text {surveyed }}=81\right)$. The slope had a significant positive effect in $2001(0.015 \pm 0.004, \mathrm{p}=0.0007)$, but not in $2002(0.011 \pm 0.007, \mathrm{p}=0.105), 2003(-0.001$ $\pm 0.009, \mathrm{p}=0.89)$, or $2004(0.018 \pm 0.011, \mathrm{p}=0.10)$.

Table 1. Number of sightings, mean group size, standard deviation (SD), encounter rate (ER) and abundance index (AI) calculated in relation to the observation effort (i.e. $4926 \mathrm{~km}$ ) over the study area in summer. Asterisks indicate species that were involved in multi-species sightings (number of multi-species sightings are given in brackets). Common and striped dolphins were seen together on 18 occasions. Pilot whales were seen together with sperm whales on 5 occasions and with bottlenose dolphins on 14 occasions

\begin{tabular}{|lccccccc|}
\hline Species & $\begin{array}{c}\text { Number of } \\
\text { groups seen }\end{array}$ & $\begin{array}{c}\text { Number of } \\
\text { groups approached }\end{array}$ & $\begin{array}{c}\text { Mean group } \\
\text { size }\end{array}$ & Range & SD & ER & AI \\
\hline $\begin{array}{l}\text { Common dolphin* } \\
\text { Delphinus delphis }\end{array}$ & $113(18)$ & $113(18)$ & 35.73 & $1-250$ & 42.39 & 2.29 & 81.97 \\
$\begin{array}{l}\text { Striped dolphin* } \\
\text { Stenella coeruleoalba }\end{array}$ & $118(18)$ & $110(18)$ & 130.38 & $1-2000$ & 222.24 & 2.40 & 291.14 \\
$\begin{array}{l}\text { Bottlenose dolphin* } \\
\text { Tursiops truncatus }\end{array}$ & $63(14)$ & 59 & 23.54 & $1-200$ & 33.26 & 1.28 & 28.20 \\
$\begin{array}{l}\text { Long-finned pilot whale* } \\
\text { Globicephala melas }\end{array}$ & $122(14,5)$ & $113(14,5)$ & 33.22 & $1-160$ & 31.57 & 2.48 & 76.20 \\
$\begin{array}{l}\text { Sperm whale* } \\
\text { Physeter macrocephalus }\end{array}$ & $130(5)$ & $85(5)$ & 1.87 & $1-4$ & 0.64 & 2.64 & 3.23 \\
$\begin{array}{l}\text { Killer whale } \\
\text { Orcinus orca }\end{array}$ & 33 & 32 & 7.94 & $3-13$ & 3.72 & 0.67 & 5.16 \\
$\begin{array}{l}\text { Fin whale } \\
\text { Balaenoptera physalus }\end{array}$ & 3 & 3 & 1 & 1 & 0.00 & 0.06 & 0.06 \\
$\begin{array}{l}\text { Non-identified } \\
\text { Totals }\end{array}$ & 24 & 4 & - & - & - & - & - \\
\hline
\end{tabular}


Table 2. Generalised additive mixed models of the presence/absence data of the 6 odontocete species commonly encountered in the Strait of Gibraltar in relation to the observation effort and bathymetry. The 'shape/edf' column indicates the direction (positive or negative) and the equivalent degrees of freedom (edf) of the relationship. Edf of 1 indicates linear relationships, whereas values above indicate non-linear effects. Spatial autocorrelation ranges are given in kilometres

\begin{tabular}{|c|c|c|c|c|c|c|}
\hline Species & Term & Shape/edf & $\mathrm{p}$-value & $\begin{array}{c}\text { Correlation } \\
\text { structure (range) }\end{array}$ & Scale estimate & Adjusted $\mathrm{R}^{2}$ \\
\hline $\begin{array}{l}\text { Common dolphin } \\
\text { Delphinus delphis }\end{array}$ & $\begin{array}{c}\text { Intercept } \\
\text { Effort } \\
\text { Slope }\end{array}$ & $\begin{array}{c}- \\
+/ 1 \\
+/ 1\end{array}$ & $\begin{array}{r}<0.001 \\
0.004 \\
0.002\end{array}$ & Spherical (8.9) & 1.00 & 0.26 \\
\hline $\begin{array}{l}\text { Striped dolphin } \\
\text { Stenella coeruleoalba }\end{array}$ & $\begin{array}{c}\text { Intercept } \\
\text { Effort } \\
\text { Depth } \\
\text { Slope }\end{array}$ & $\begin{array}{l}- \\
+/ 1 \\
+/ 1 \\
+/ 1\end{array}$ & $\begin{array}{c}<0.001 \\
<0.001 \\
0.01 \\
0.021\end{array}$ & Exponential (1.3) & 0.85 & 0.34 \\
\hline $\begin{array}{l}\text { Bottlenose dolphin } \\
\text { Tursiops truncatus }\end{array}$ & $\begin{array}{c}\text { Intercept } \\
\text { Effort } \\
\text { Slope } \\
\text { Depth }\end{array}$ & $\begin{array}{l}- \\
+/ 1 \\
+/ 1 \\
+/ 1\end{array}$ & $\begin{array}{r}<0.001 \\
<0.001 \\
0.034 \\
0.058\end{array}$ & Spherical (7.7) & 0.61 & 0.30 \\
\hline $\begin{array}{l}\text { Long-finned pilot whale } \\
\text { Globicephala melas }\end{array}$ & $\begin{array}{c}\text { Intercept } \\
\text { Effort } \\
\text { Depth }\end{array}$ & $\begin{array}{c}- \\
+/ 1 \\
+/ 1.8\end{array}$ & $\begin{array}{c}<0.001 \\
<0.001 \\
0.04\end{array}$ & - & 0.92 & 0.48 \\
\hline $\begin{array}{l}\text { Sperm whale } \\
\text { Physeter macrocephalus }\end{array}$ & $\begin{array}{c}\text { Intercept } \\
\text { Effort } \\
\text { Depth }\end{array}$ & $\begin{array}{c}- \\
+/ 1 \\
+/ 1\end{array}$ & $\begin{array}{c}<0.001 \\
<0.001 \\
0.02\end{array}$ & - & 1.08 & 0.26 \\
\hline $\begin{array}{l}\text { Killer whale } \\
\text { Orcinus orca }\end{array}$ & $\begin{array}{l}\text { Intercept } \\
\text { Effort }\end{array}$ & $\begin{array}{l}- \\
+/ 1\end{array}$ & $\begin{array}{r}<0.001 \\
0.003\end{array}$ & $\begin{array}{c}\text { Spherical, } \\
\text { no nugget (4.6) }\end{array}$ & 0.75 & 0.08 \\
\hline
\end{tabular}

Bottlenose dolphins Tursiops truncatus were encountered in $10.0 \%$ of the quadrats sampled (Fig. 7). Their presence was related to observation effort, and positively associated to steeper sea bottoms (linear relationship, see Table 2). Bottlenose dolphins also tended to be found in the deeper areas, although the relationship was not or marginally significant $(\mathrm{p}=0.058)$.
Pilot whales Globicephala melas and sperm whales Physeter macrocephalus were encountered in 12.0 and $5.3 \%$, respectively, of the quadrats sampled. The distribution of both species was confined to the southern parts of the study area (Figs. 8 \& 9). Pilot whale data were too sparse to fit complex models accounting for the spatial autocorrelation of the data (spatial models had very poor convergence and

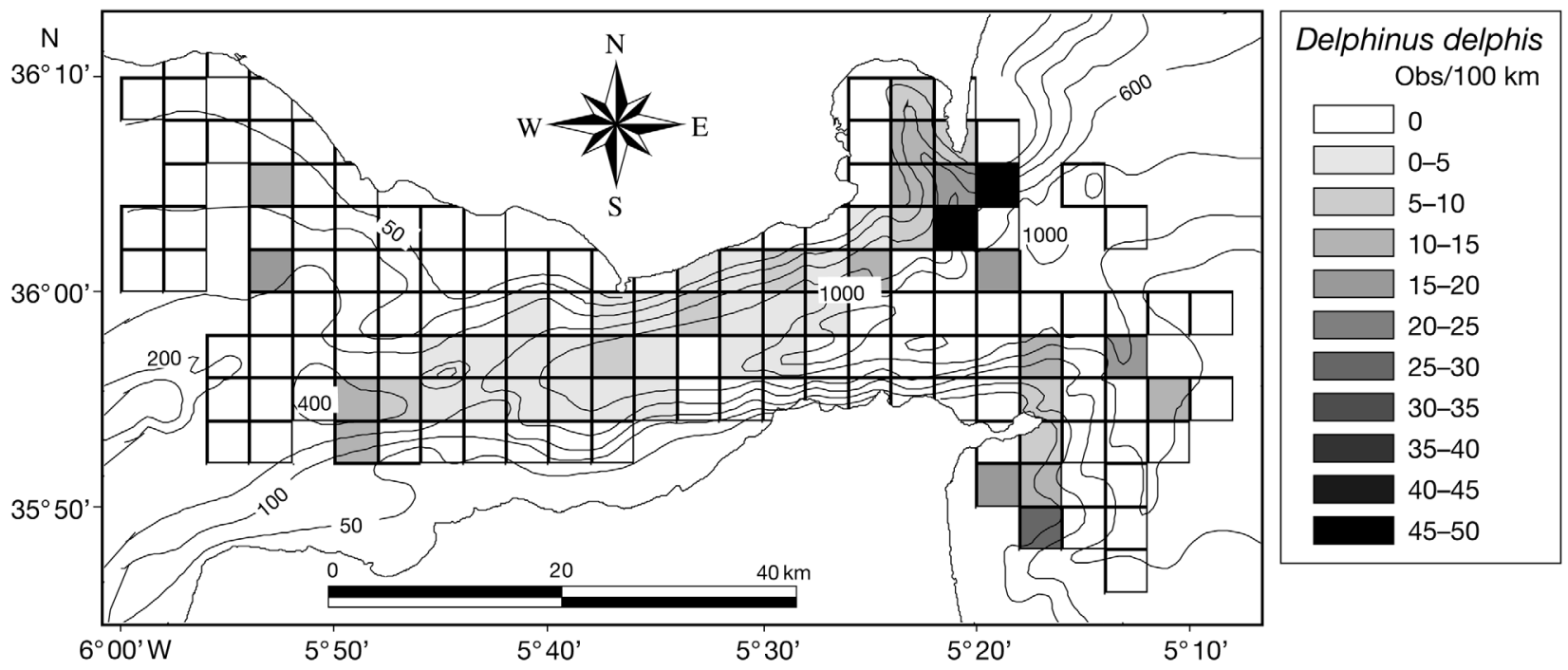

Fig. 5. Delphinus delphis. Distribution of encounter rates of common dolphins over the study area during this study 


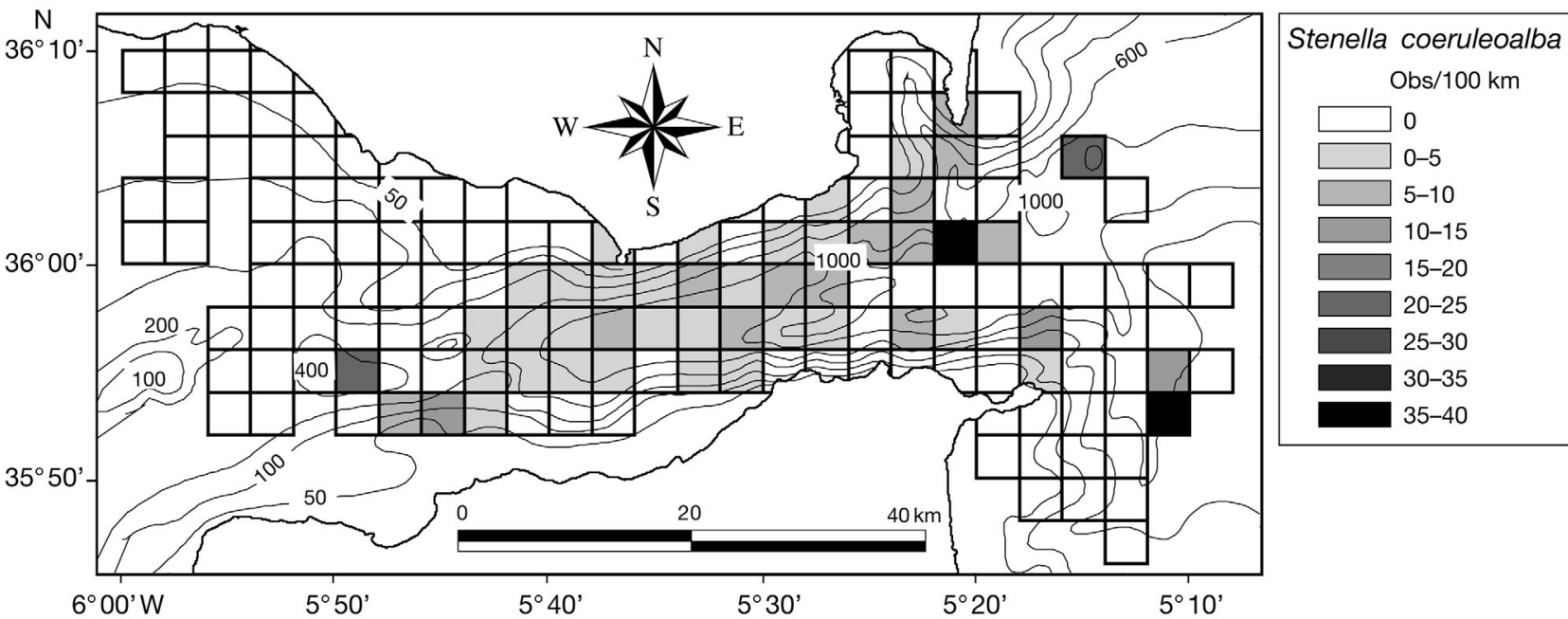

Fig. 6. Stenella coeruleoalba. Distribution of encounter rates of striped dolphins over the study area during this study
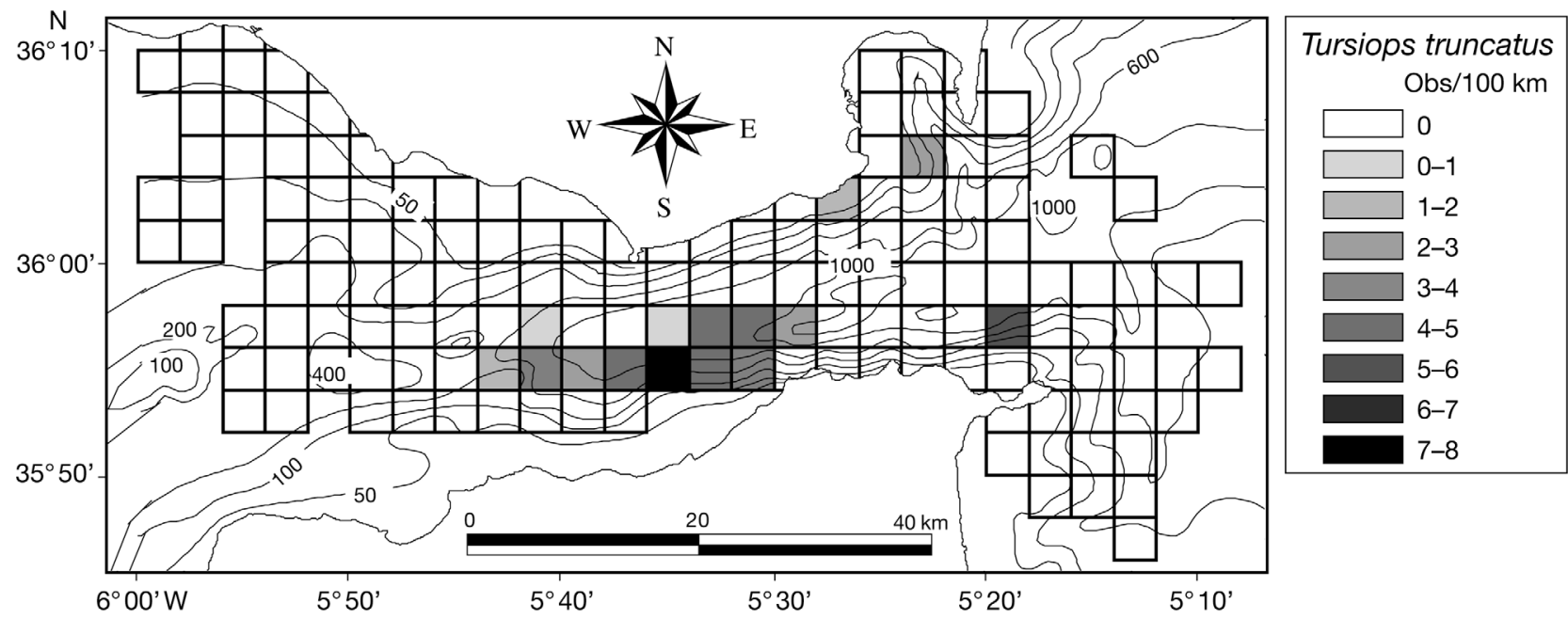

Fig. 7. Tursiops truncatus. Distribution of encounter rates of bottlenose dolphins over the study area during this study

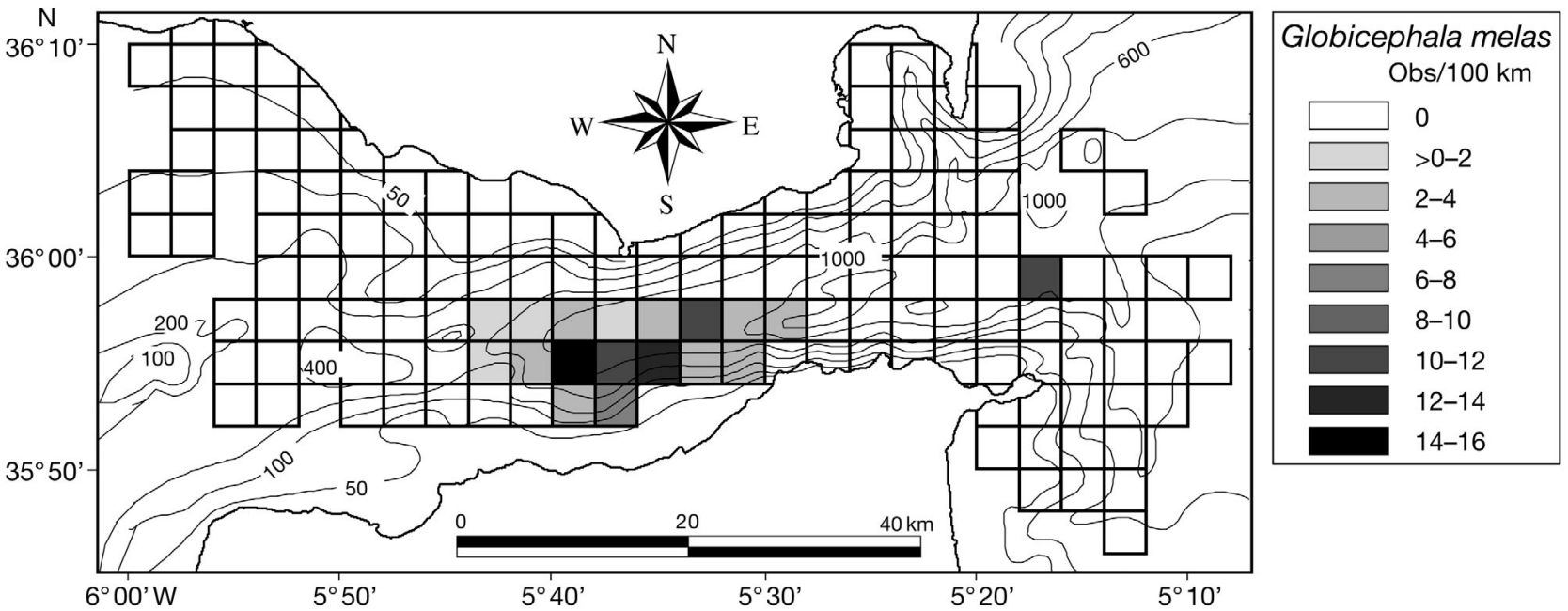

Fig. 8. Globicephala melas. Distribution of encounter rates of long-finned pilot whales over the study area during this study 


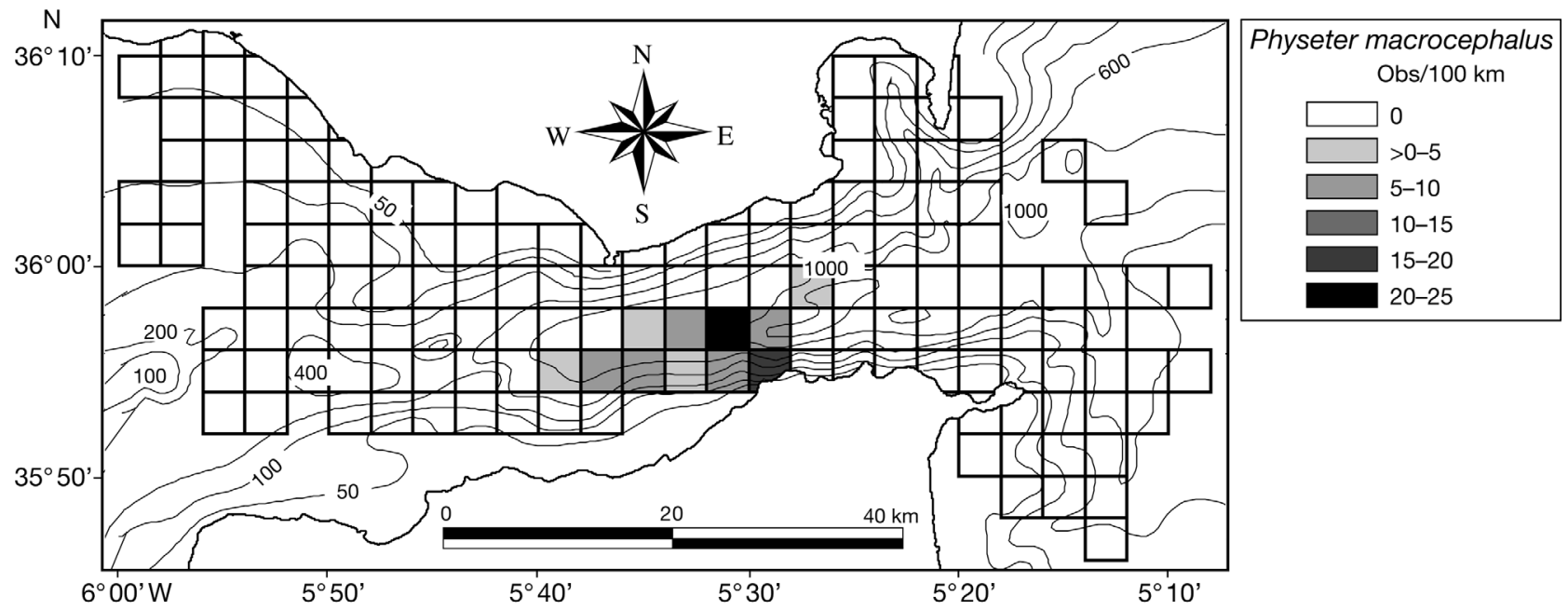

Fig. 9. Physeter macrocephalus. Distribution of encounter rates of sperm whales over the study area during this study

residual diagnostics). Nevertheless, assuming spatially independent data, we found a non-linear effect of depth on pilot whale presence (Table 2). Pilot whales were less likely to be encountered in areas shallower than $300 \mathrm{~m}$ depth, and showed similar preference for all depths between 300 and $800 \mathrm{~m}$. Sperm whale presence was positively and linearly correlated to depth (Table 2).

Killer whales Orcinus orca occurred in $7.2 \%$ of the quadrats sampled. They were encountered in the shallower waters of the south-western part of the research area (Fig. 10). However, there was no statistically significant relationship between killer whale presence and depth or slope, probably owing to their low encounter rate. However, visual comparison of killer whale sightings (Fig. 10) and tuna fishery (Fig. 11) shows an unambiguously strong match.

\section{Spatial association-segregation between cetacean species}

The standard deviations of the observed pairwise association indices were significantly higher than those from permuted data (simple ratio index: $p<0.001$; halfweight index: $p<0.001$ ), so the null hypothesis of a random association in the space of species could be rejected. The cluster diagram (Fig. 12) and visual observation of the distribution maps (Figs. 5 to 10) show that 3 main groups of cetaceans can be distinguished. (1) Common dolphins and striped dolphins tended to be spatially associated with each other. The overlap between common dolphins and, to a lesser extent, between striped dolphins and the other cetacean species was limited. (2) Bottlenose dolphins, long-finned pilot whales and sperm whales shared a large part of their

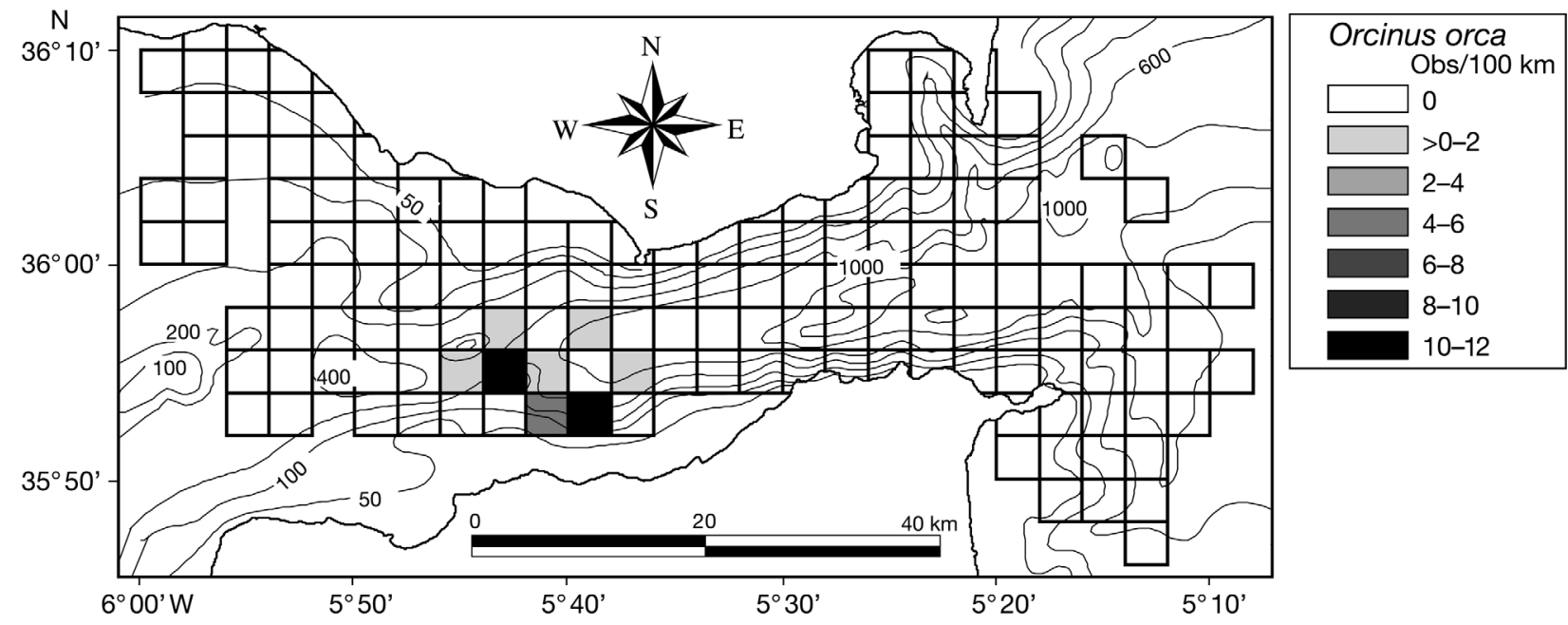

Fig. 10. Orcinus orca. Distribution of encounter rates of killer whales over the study area during this study 


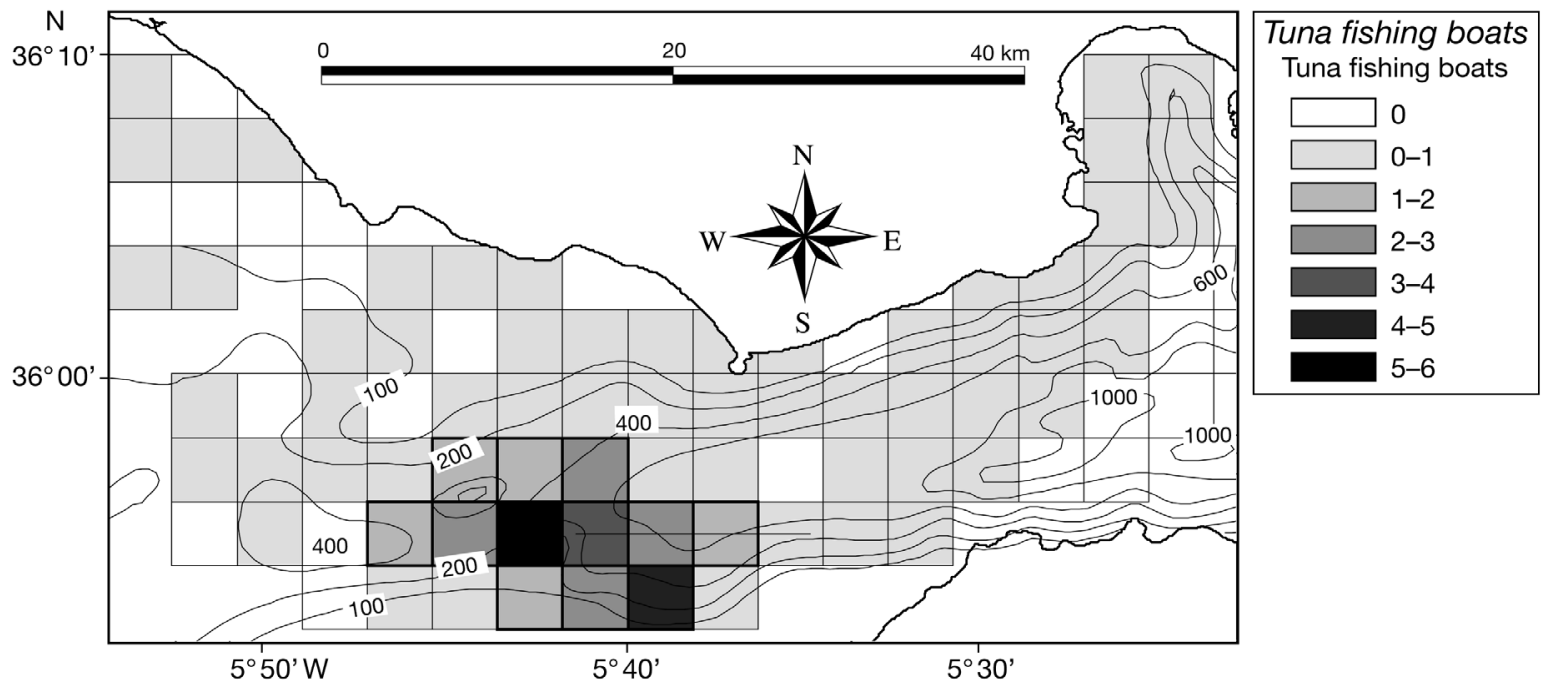

Fig. 11. Distribution of sightings of tuna boats in the Strait of Gibraltar established from 2008 sampling stations (see 'Materials and methods')

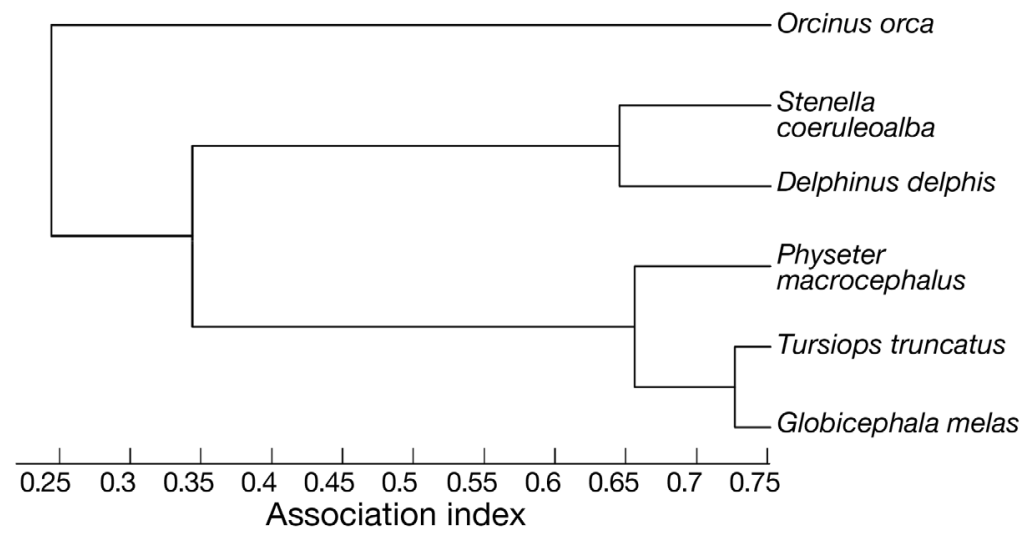

Fig. 12. Average-linkage cluster analyses of association (half-weight association index) between the different cetacean species in the Strait of Gibraltar (cophenetic correlation coefficient $=0.90$ )

habitat within the strait. (3) The smallest overlap with any other cetacean species was observed for killer whales. All species but fin and killer whales were involved in multi-species sightings (Table 1). A total of $15 \%$ of the sightings of the striped dolphins was seen with common dolphins, and $14 \%$ of the sightings of common dolphins was seen with striped dolphins; 11 and $4 \%$ of the sightings of long-finned pilot whales were seen with bottlenose dolphins and sperm whales, respectively, representing 22 and $4 \%$ of the sightings of bottlenose dolphins and sperm whales, respectively.

\section{DISCUSSION}

The Strait of Gibraltar is characterised by 7 species of cetaceans, which were observed within the scope of this study. Most of these species are abundant, reaching an ER of between 291.14 and 3.23 ind. per $100 \mathrm{~km}$ of effort for striped dolphins Stenella coeruleoalba and killer whales Orcinus orca, respectively. Seven of the 9 species of cetaceans regularly seen in the Mediterranean Sea (Reeves \& Notarbartolo di Sciara 2006) have been described in the Strait of Gibraltar. One may suggest that the relatively high diversity of cetacean species observed at the entrance of the Mediterranean Sea could be related to a large number of cetaceans transiting in and out of the Mediterranean Sea. However, longterm, photo-identification work indicates that individual sperm whales Physeter macrocephalus, pilot whales Globicephala melas, bottlenose dolphins Tursiops truncatus, killer whales O. orca and common dolphins Delphinus delphis at least are resident in the strait in summer (de Stephanis unpubl. data), while the status of striped dolphins $S$. coeruleoalba needs to be studied. Reul et al. (2002) estimated that $5570 \mathrm{t} \mathrm{C} \mathrm{d}^{-1}$ were transported towards the Mediterranean Sea, while 1140 t C were exported daily towards the Atlantic by the deep Mediterranean outflow. The strait is characterised by mixing processes through a pulsed upwelling induced by the tides and constrained by the strait's bathymetry (Echevarría et al. 2002). These phenomena are reflected in the boiling-water phenomena, occurring close to the Kamara Ridge, and that produce vertical advection and mixing processes (Bruno et al. 2002). The area is then a highly productive area, and the most likely hypothesis to 
explain the high density of cetaceans is prey availability being enhanced within the Strait of Gibraltar.

In this study, data were pooled over $4 \mathrm{yr}$ in order to produce statistically robust habitat-cetacean models. As a consequence, we only examined the static determinants of cetacean distribution, i.e. bathymetric characteristics, which do not change from one year to another. In this context, pooling the distribution data over several years should have reduced the noise due to unknown environmental fluctuations and provided more robust relationships with bathymetry. In fact, where the analyses could be run on individual years, unstable results emerged, which could be attributed to insufficient data available. With temporally 'averaged' data, the spatial correlations we detect are unlikely caused by short-term spatial interactions such as conspecific attraction, but may rather reflect the spatial structures generated by un-modelled environmental factors.

Three distinct groups of species were identified according to their distribution within the strait. Common and striped dolphins had a larger, broader distribution and a preference for the northern part of the study area, being mainly concentrated in deep waters and along the north edge of the northern channel of the Strait of Gibraltar (Figs. 5 \& 6). Bottlenose dolphins, pilot whales and sperm whales shared a large part of their foraging habitat, and were mainly found over deep waters, over the main channel of the Strait of Gibraltar (Figs. 7 to 9). The third group included a single species: the killer whales, which were more commonly seen in the western part of the study area. The differences in the spatial distribution between these 3 groups are likely related to their respective foraging ecology and, in particular, the fact that they are foraging in different water masses.

There is little information on the diet of these species in the study area. According to other studies, both common and striped dolphins appear to be opportunistic feeders (Young \& Cockcroft 1994, Gannier 1995), targeting mainly small neritic fishes and cephalopods. The small meso-pelagic cephalopods and myctophids tend to be higher diet components for the striped dolphins (Blanco et al. 1995, Santos et al. 1996) than for the common dolphins (Young \& Cockcroft 1994, Santos et al. 1996). These differences may contribute to the occurrence of striped dolphins over deeper waters compared to common dolphins. Interestingly, both species are more abundant in the northern part of the strait, where enriched Atlantic Spanish shelf waters are circulating (Van Geen \& Boyle 1988) and where plankton biomass concentration is higher and current velocities are lower than in the central and southern parts of the strait (Reul et al. 2002). These ecological conditions may be more favourable for fishes, but small cephalopods feeding on zooplankton are also supported. Diving studies of common dolphins and 2 Stenella species have shown that most dives are shallower than $150 \mathrm{~m}$ (Davis et al. 1996). This suggests that both common dolphins and striped dolphins are likely to restrict most, if not all, of their feeding activity to the layer of inflowing Atlantic waters. Furthermore the Atlantic-Mediterranean water interface may act as a boundary for their fish and squid prey and, as this interface is shallower in the northern part of the strait, it may enhance their foraging success in this area.

Within the second group of cetaceans, pilot whales and sperm whales are known to be mainly squid eaters (Desportes \& Mouritsen 1993, Gannon et al. 1997, Santos et al. 1999) and deep divers (Watkins et al. 1993, Baird et al. 2002). Thus, the spatial summer distribution of these 2 species within the strait is likely to be indicative of the distribution of larger squid species encountered in the strait. However, it is unclear why bottlenose dolphins, which are mainly piscivorous (Barros \& Odell 1990, Gannier 1995), tend to be spatially associated with sperm whales and pilot whales.

Several diving studies on sperm whales have shown that they dive regularly to depths $>1000 \mathrm{~m}$ (Watkins et al. 1993), and, thus, they are able to reach the sea floor throughout the study area. Interestingly, the ER of sperm whale is higher just west of the Central Ridge, which separates the northern and main channels. The other area of higher ER of sperm whales is found east of the Kamara Ridge. This suggests that sperm whales may forage in the deepest areas of the central strait. Pilot whales are also known to be relatively deep divers, reaching depths between 200 and $600 \mathrm{~m}$, with a maximum recorded depth of $828 \mathrm{~m}$ in the Ligurian Sea (Baird et al. 2002). Pilot whales feed mainly on neritic and oceanic squids and to a lesser extent on fishes that are most common at depths between 100 and $1000 \mathrm{~m}$ (Desportes \& Mouritsen 1993, Gannon et al. 1997). However, these prey exhibit vertical movements that may allow the pilot whales to catch them at night, when they are closer to the surface, while they may be inaccessible during the day (Desportes \& Mouritsen 1993, Baird et al. 2002). The spatial distribution in summer of long-finned pilot whales and sperm whales indicates that both species are likely to exploit squids-and possibly fishes-associated with the deep outflow of Mediterranean waters.

Bottlenose dolphins present a similar distribution to sperm whales. However, their dives are usually between 10 and $50 \mathrm{~m}$ (Hastie et al. 2006). Therefore, they are likely to restrict their feeding to the surface Atlantic water inflow. Bottlenose dolphins are opportunistic feeders and are considered to have a diet mainly based on demersal prey (Barros \& Odell 1990, 
Gannier 1995), which seems unlikely in our study because of their distribution over very deep waters, where pelagic feeding appears to be the only possible foraging strategy. As we lack information on their diet over the study area, we are unable to determine if they are feeding mainly on the pelagic prey associated with the deep Mediterranean outflow migrating to the surface at night, or if they feed on the pelagic prey associated with the Atlantic water inflow or both.

Killer whale distribution was the most distinctive when compared to other cetacean species occurring within the strait. Killer whales were seen interacting with the drop line fishery for bluefin tuna migrating out of the Mediterranean Sea after the completion of breeding. The summer killer whale distribution is spatially closely associated with the location of that fishery, which is concentrated east of the Kamara Ridge, for the Moroccan fleet, and in the pass between Monte Seco and Monte Tartesos, for the Spanish fleet.

The frequency of fin whale sightings in summer is very low and consistent with recent results indicating that most of the fin whale observations take place from fall to spring (de Stephanis unpubl. data). Furthermore, the catches reported by Aguilar (2006) were made in the Atlantic Ocean (Gulf of Cádiz), between 32 and $37^{\circ} \mathrm{N}$, and not in the Strait of Gibraltar itself, so a high presence of this species in the study area was not expected.

Research into producing reliable variance estimates for spatial model predictions has been identified as a priority for cetacean distribution studies (Williams et al. 2006). One of the conditions for this is that the variance in the data themselves is properly modelled.

The present study shows that it is possible to estimate habitat-cetacean models that account for the under- or over-dispersion of errors, as well as their spatial autocorrelation. However, in some cases, models could not be estimated, or could only be after some simplification (e.g. not including spatial autocorrelation, see pilot whale or sperm whale models in Table 2). Likewise, reducing the amount of data by fitting models for individual years often resulted in unreliable models (e.g. fitting algorithms did not converge or residuals grossly violated normality or homoscedasticity assumptions). This suggests that despite the intensive observation effort and the relatively large number of sightings, our data set is near the minimum required to estimate robust habitat-cetacean associations.

Interestingly, most of the relationships we found between cetacean presence (or abundance) and covariates were linear or had very simple non-linear shapes (e.g. pilot whale), in contrast with many other studies using GAMs (e.g. Forney 2000, Ferguson et al. 2006, Williams et al. 2006). One possible explanation is that the range of depths found in the Strait of Gibraltar is too small to observe non-linear relationships such as thresholds or mid-range optima. However, there is little doubt that careful treatment of error dispersion and spatial autocorrelation were the main factors responsible for the parsimony of our models. Both overdispersion and spatial autocorrelation tend to inflate Type I error, that is, make unimportant covariates appear unduly significant (Keitt et al. 2002, Redfern et al. 2006). In the case of GAMs, this also tends to exaggerate the non-linearity of the relationships with covariates. In fact, experiences during the development of our models confirmed that in this data set, overly complex additive terms were very easy to obtain when failing to account for one or both of these features. As a consequence, we concur with Redfern et al. (2006) in that the error structure and non-independence of the data (e.g. spatial autocorrelation) should be systematically controlled in habitat-cetacean studies.

Acknowledgements. This work was co-funded by CIRCE from 2001 to 2004, the Autonomous City of Ceuta in 2001 and the Life Nature Project (LIFE02NAT/E/8610) between 2002 and 2004. Special thanks are due to P. Sanchez from the 'Centre Mediterrani d'Investigacions Marines i Ambientals (CSIC)' in Barcelona and Y. Cherel from CEBC-CNRS for their comments on squid distribution in the Alborán Sea and the Gulf of Cadiz. We are also very grateful to the CIRCE staff and assistants in the field, P. Gozalbes, E. Pubill, R. Esteban and M. Fernández Casado. Thanks also to A. Cañadas, E. Urquiola, D. Desmonts, A. Aguilar, Y. Yaget and R. Sagarminaga for their help, support and comments. Many thanks also to all the whale watching companies present in the strait, Tumares S.L., Whale watch España, Aventura Marina and FIRMM for their comments on this manuscript and their help at sea. This research was conducted using software Logger 2000 developed by the International Fund for Animal Welfare (IFAW) to promote benign and non-invasive research.

\section{LITERATURE CITED}

Aguilar A (2006) Catches of fin whales around the Iberian Peninsula: statistics and sources. Joint NAMMCO/IWC Scientific workshop on the catch history, stock structure and abundance of North Atlantic fin whales. Document SC/14/FW/17-SC/M06/FW17, International Whaling Commission, Reykjavik

Baird RW, Borsani JF, Hanson MB, Tyack PL (2002) Diving and night-time behaviour of long-finned pilot whales in the Ligurian Sea. Mar Ecol Prog Ser 237:301-305

Barros NB, Odell DK (1990) Food habits of bottlenose dolphins in the southeastern United States. In: Leatherwood $\mathrm{S}$, Reeves RR (eds) The bottlenose dolphin. Academic Press, San Diego, CA, p 309-328

Bejder L, Fletcher D, Bräger S (1998) A method for testing association patterns of social animals. Anim Behav 56:719-725

Blanco C, Aznar J, Raga JA (1995) Cephalopods in the diet of the striped dolphin Stenella coeruleoalba from the western Mediterranean during an epizootic in 1990. J Zool Lond 237:151-158

Bruno M, Alonso J, Cózar A, Vidal J, Echevarría F, Ruiz J, Ruiz-Cañavate A, Gómez F (2002) The boiling water phe- 
nomena at Camarinal Sill, the Strait of Gibraltar. DeepSea Res II 49(19):4097-4113

Cañadas A, Sagarminaga R, de Stephanis R, Urquiola E, Hammond P (2005) Habitat preference modelling as a conservation tool: proposals for marine protected areas for cetaceans in southern Spanish waters. Aquat Conserv 15: 495-521

Davis RW, Worthy GAJ, Wursig B, Lynn SK, Townsend FI (1996) Diving behavior and at sea movements of an Atlantic spotted dolphin in the Gulf of Mexico. Mar Mamm Sci 12:569-581

Davis RW, Fargion GS, May N, Leming TD, Baumgartner M, Evans WE, Hansen LJ, Mullin K (1998) Physical habitat of cetacean along the continental slope in the north-central and western Gulf of Mexico. Mar Mamm Sci 14(3): 490-507

Desportes G, Mouritsen R (1993) Preliminary results on the diet of long-finned pilot whales off the Faroe Islands. Rep Int Whal Comm Spec Issue 14:305-324

Echevarría F, García Lafuente J, Bruno M, Gorsky G and 15 others (2002) Physical-biological coupling in the Strait of Gibraltar. Deep-Sea Res II 49:4115-4130

Ferguson MC, Barlow J, Fiedler P, Reilly SB, Gerrodette T (2006) Spatial models of delphinid (family Delphinidae) encounter rate and group size in the eastern tropical Pacific Ocean. Ecol Model 193:645-662

Forney KA (2000) Environmental models of cetacean abundance: reducing uncertainty in population trends. Biol Conserv 14:1271-1286

Gannier A (1995) Les cétacés de Méditerranée nord-occidentale: estimation de leur abondance et mise en relation de la variation saisonnière de leur distribution avec l'écologie du milieu. Master thesis, Ecole Pratique des Hautes Etudes, Montpellier

Gannon DP, Read AJ, Craddock JE, Fristrup KM, Nicolas JR (1997) Feeding ecology of long-finned pilot whales Globicephala melas in the western North Atlantic. Mar Ecol Prog Ser 148:1-10

Gil de Sola L (1993) Las pesquerías demersales del Mar de Alborán (sur-Mediterráneo Ibérico), evolución en los últimos decenios. Inf Tec Inst Esp Oceanogr 142:1-179

Ginsberg JR, Young TP (1992) Measuring association between individuals or groups in behavioural studies. Anim Behav 44:377-379

Hastie GD, Wilson B, Thompson PM (2006) Diving deep in a foraging hotspot: acoustic insights into bottlenose dolphin dive depths and feeding behaviour. Mar Biol 148: $1181-1188$

Hooge PN, Eichenlaub B (2000) Animal movement extension to Arcview, Ver 2.0. Alaska Science Center-Biological Science Office, U.S. Geological Survey, Anchorage, AK. Available at www.absc.usgs.gov/glba/ gistools/index.htm \#ANIMAL MOVEMENT

Keitt TH, Bjornstad ON, Dixon PM, Citron-Pousty S (2002) Accounting for spatial pattern when modelling organism-environment interactions. Ecography 25:616-625

Kinder TH, Parrilla G, Bray NA, Burns DA (1988) The hydrographic structure of the Strait of Gibraltar. In: Almazan JL, Bryden H, Kinder T, Parrilla G (eds) Seminario sobre la oceanografía física del Estrecho de Gibraltar, Madrid, p 55-67

Lacombe H, Richez C (1982) The regime of the Strait of Gibraltar. In: Nihoul JCJ (ed) Hydrodynamics of semienclosed seas. Elsevier, Amsterdam, p 13-73
Manly BFJ (1994) Multivariate statistical methods: a primer Chapman \& Hall, New York

Piatt JF, Wetzel J, Bell K, DeGange AR and 5 others (2006) Predictable hotspots and foraging habitat of the endangered short-tailed albatross (Phoebastria albatrus) in the North Pacific: implications for conservation. Deep-Sea Res Part II 53:370-386

Pinheiro JC, Bates DM (2000) Mixed-effects models in S and S-PLUS. Springer Verlag, New York

R Development Core Team (2006) R: a language and environment for statistical computing. R Foundation for Statistical Computing, Vienna. Available at www.R-project.org

Redfern JV, Ferguson MC, Becker EA, Hyrenbach KD and 15 others (2006) Techniques for cetacean-habitat modeling. Mar Ecol Prog Ser 310:271-295

Reeves R, Notarbartolo di Sciara G (eds) (2006) The status and distribution of cetaceans in the Black Sea and Mediterranean Sea. IUCN Centre for Mediterranean Cooperation, Malaga

Reul A, Vargas JM, Jiménez-Gómez F, Echevarría F, Garcialafuente J, Rodriguez J (2002) Exchange of planktonic biomass through the Strait of Gibralatar in late summer conditions. Deep-Sea Res Part II 49:4131-4144

Roussel E (1999) Les cétacés dans la partie orientale du Détroit de Gibraltar au printemps: indications d'écologie. Master thesis, Ecole Pratique des Hautes Etudes, Montpellier

Sanjuán A, Zapata C, Álvarez G (1994) Mytilus galloprovincialis and $M$. edulis on the coasts of the Iberian Peninsula. Mar Ecol Prog Ser 113:131-146

Santos MB, Pierce GJ, López A, Barreiro A, Guerra A (1996) Diets of small cetaceans stranded NW Spain. ICES Comm Meet N:11:?

Santos MB, Pierce GJ, Boyle PR, Reid RJ and 7 others (1999) Stomach contents of sperm whales Physeter macrocephalus stranded in the North Sea 1990-1996. Mar Ecol Prog Ser 183:281-294

SEC (Sociedad Española de Cetáceos) (1999) Recopilación, análisis, valoración y elaboración de protocolos sobre las labores de observación, asistencia a varamientos y recuperación de mamíferos y tortugas marinas de las aguas españolas. Technical Report Sociedad Española de Cetáceos, Secretaria General de Medio Ambiente, Ministerio de Medio Ambiente Español, Madrid

Silvani L, Gazo M, Aguilar A (1999) Spanish driftnet fishing and incidental catches in the western Mediterranean. Biol Conserv 90:79-85

Van Geen A, Boyle E (1988) Atlantic water masses in the Strait of Gibraltar: inversion of trace metal data. In: Almazan JL, Bryden H, Kinder T, Parrilla G (eds) Seminario sobre la oceanografía física del Estrecho de Gibraltar. SECEG, Madrid, p 68-81

Watkins WA, Daher MA, Fristrup KM, Howald TJ, Nortobartolo di Sciara G (1993) Sperm whales tagged with transponders and tracked underwater by sonar. Mar Mamm Sci 9:55-67

Williams R, Hedley SL, Hammond PS (2006) Modelling distribution and abundance of Antarctic baleen whales using ships of opportunity. Ecol Soc 11(1):1

Wood SN (2006) Generalized additive models: an introduction with R. Chapman and Hall/CRC, Boca Raton, FL

Young DD, Cockcroft VG (1994) Diet of common dolphins (Delphinus delphis) off the south-east coast of southern Africa: Opportunism or specialization? J Zool Lond 234:41-53

Submitted: December 31, 2006; Accepted: July 18, 2007

Proofs received from author(s): January 3, 2008 